\title{
Women, Religion and COVID-19: Cohesive Agency, Resilience-Building and Inter-spatial Performance
}

\author{
Leonard Chrysostomos Epafras ${ }^{1}$, Ida Fitri Astuti ${ }^{2}$ \\ \{leonard_epafras@staff.ukdw.ac.id'1 ,ida.fitri.a@mail.ugm.ac.id ${ }^{2}$ \} \\ Universitas Kristen Duta Wacana, Yogyakarta ${ }^{1}$, Indonesian Consortium for Religious Studies, \\ Yogyakarta ${ }^{2}$
}

\begin{abstract}
The present article is an outcome of four-month research, from May to August 2020 entitled Reshaping New Urban Living: Indonesian Women and Coronavirus. It focuses on women's experiences during pandemic through four observations, i.e., on women's workers, social-religious women's activists, women in religious minority groups, and on women with disability. The insights drew from sixty-eight women of six religious' preferences, including the adherents of ancestral religion in ten cities in Indonesia. Our research confirmed a cheerless circumstance of women, which in many cases is a prolongation of the pre-pandemic situation. Nevertheless, we testified different levels of women's impressive performance such as in the emergence of domestic level religious authorities, cohesive familial relationship, and others. However, in large part there was inadequate deliberation of meaning making from the traditional religious authority upon women's performance, in particular for women with disabilities.
\end{abstract}

Keywords: Indonesian women, religion and pandemic, religious experience, women experience, COVID-19.

\section{Introduction}

April 21, 2020 was distinct from the other April Twenty-Firsts. The Kartini Day, as it is renowned, the Indonesian Women's Emancipation Day, passed without open and public celebration, most of it reformatted for online display. Online media however, reporting the women's impressive performance in different walks of lives as the outcome of historical achievement of emancipatory process since the pre-colonial period. The regular celebration of Kartini Day usually created a space of public criticism as it was more concerned with outward appearance, symbolic performance rather than the substance of elevating women's status and condition. The pandemic heightened this cynicism, as what is considered as achievement, turned out creating extra burden and new demand for women's social role [14]. Female presidents of the world might be praised for their responsiveness in dealing with pandemic and it also goes to the numerous women's initiatives and creativity in the household level. But in the larger geopolitical context, women are "disproportionately" demanded for a larger and active role in fixing the social challenges such as being a peacemaker, maintainer social resilience, and so forth [21].

The effect of the pandemic toward women evolved and still need further assessment to be aware of its full impact $[2,23]$. Earlier periods of pandemic indicated women's low exposure 
to the virus against men, as men were more mobile and as women were more disciplined in maintaining health protocol $[4,17,24]$. Nevertheless, beyond that, in terms of social position women are persistently vulnerable. They were susceptible to the challenge of reproductive health as the governmental program of family planning almost solely relied on women, to the economic downturn that affected the government and education sector, which was dominated by women. Besides, women have the vulnerability in the informal sector, are exposed to domestic violence, and bear multiple burdens as the consequence of work and school from home $[2,4]$.

In 2019 , the average household size of Indonesian families is 3.9, in which $37 \%$ women were housekeepers [3]. Mid- and large size families suffered so much with the pandemic in term to maintain domestic wealth and healthy emotional management. We might expect the post-pandemic condition of families trapped in low-net wealth conditions [cf. 18].

Besides the vulnerability in health and social space, stronger women's position before the legal stipulation is still an uphill struggle. The reluctance of lawmakers on the realization of the much expected sexual violence bill (Rancangan Undang-Undang Penghapusan Kekerasan Seksual, RUU-PKS), by excluded it from the National Legislation Program (Prolegnas) priority list aggravated women's position, as the pandemic attested the soar of domestic violence [19]. While the bill definitely could not cope with the pandemic situation, the urgency of it effectuated in the post-pandemic.

Nevertheless, in such complicated situations, Indonesian women displayed disproportionate resilience and became the agent of domestic and social cohesion. They also to a degree shaped the urban living through their inter-spatial performance, including in the virtual realm. Despite extra challenges faced by women with disabilities, they maintained creativity and found new meaning of social solidarity. The following is the presentation of our research and observations to them.

The present article is the outcome of research that attempts to understand women's conditions and their maneuver among social spaces that shaped urban living during the pandemic. Within the above intricacies, the investigation is also directed at the role of religion, both in reimagining women's status and as an element on shaping women's space. Three topics highlighted our research, i.e., cohesive agency and resilience-building, inter-spatial performance, and commonality and incommensurability of women with disabilities.

\section{Methods}

The present paper is the outcome of four-month research, conducted between May to August 2020. Due to the pandemic context of research activities, hybrid media space [cf. 16] is the main methodology through which it focused on the convergence condition of social spaces and social practices, among private, semi-private and public, online and offline, domestic and communal governance, as it informs the complicated relationship between agency and the state. It signaled the prominent role of new media and digital technology in devising women experience during the pandemic, manifested in work-from-home, physical and social distancing, shopping, selling, communication, and others.

The techniques of data collection and analysis are included, literature studies, interview and focus group discussion, social media and internet observation. This research method is employed to answer some research questions on (1) how Indonesian women respond to the COVID-19 pandemic; (2) how Indonesian women's manoeuvring among spaces (public, 
domestic, and virtual) might shape new urban living during and post-pandemic; (3) Urban living connotes at least the inter-household relationship, household-based commerce, communal and digital collective activities, urban setting of domestic affairs, women's career, and so on; (4) how does religion reimagine Indonesian women and women's status within the context of pandemic; and (5) how religion shapes women's religiosity within the context of pandemic.

We collected insights from 68 women, from ten cities, i.e., Bandung, Banda Aceh, Denpasar, Madiun, Malang, Pontianak, Ruteng-Labuan Bajo, Salatiga, Tomohon-Manado, and Yogyakarta. They were divided into four clusters of observations, i.e., women's workers, social-religious women's activists, women in religious minority groups, and women with disability. They are aged 24 to 57 years old, working in different sectors from household wives to academics. In terms of religious preferences, those consisted of 35 Muslims, 15 Christians, 10 Catholics, 5 Hindus, 1 Buddhists, and 2 Ancestral religions. Among the Muslims, there were the representatives of religious minority groups, i.e., three Ahmadis.

The selection of women's workers is more or less obvious as those reflecting the most affected group by the pandemic. Meanwhile the other three, i.e., social-religious women's activists, women in religious minority groups, and women with disability are the group gaining less attention in many researches. Those, furthermore, are more relevant to our main concern in understanding the relationship between religion and COVID-19. The cluster division was not rigid as we encountered overlapping categories, notably between socialreligious activists and women's workers.

\section{Research Results}

\subsection{Women's Workers}

We were focusing the observation of women's workers in five places, i.e., Salatiga, Malang, Tomohon-Manado, Pontianak and Bali. Altogether we collected data from 26 women, single and married, which consisted of health sector workers (nakes, tenaga kesehatan), teachers, civil servants, entrepreneurs, bank employees, pastors, university students, private sector clerks, and academics. While economic challenges in different degrees faced by most of our informants, the pressure for familial women mostly came from the extra burden for them to handle domestic and regular jobs, notably families with minors. In addition, for the health workers the most worrisome to them is becoming the potential transmitter of the virus to their families. For the single women, their challenge mostly on the undecided future and the payrolls deduction as the country faced the economic downturn.

\subsection{Social-religious Women's Activists}

Social workers' group embraced the insights from fourteen women, in two places of Madiun and Ruteng-Labuan Bajo, but also included the insights from Bali's two focus group discussions. The occupation of the informants are Catholic nuns, teachers/social workers, household women, entrepreneurs and academics. The main challenge for almost all activists and social institutions/communities is the limitation of movement. However, these women activists did a number of maneuvers to deal with it. The activities of the humanitarian group 
forced them to adjust their strategy without surrendering the substance of humanitarian actions. Some important things related to strategies to get through the pandemic include generating and implementing new (creative) ideas using safe mediums for personal health and in line with health protocols to break the chain of virus spread. Through these new platforms of activity, women activists succeeded in extracting social and humanitarian concerns from elements of society that had not yet appeared before the pandemic. They even use it to trigger social change and to appropriate it with the existing patriarchal culture.

\subsection{Women in Religious Minority Groups}

Women's experiences within the minority religious groups sought insights from the representations of Ahmadi, Hakka's, and Sunda Wiwitan's women. Altogether, we learned from ten women about their story in dealing with their position in the context of pandemic.

In general, pandemic prevented these groups from outright discrimination and persecution from the others, which usually haunted them in the pre-pandemic, notably toward Ahmadi, and Sunda Wiwitan communities. After the research period, indeed Sunda Wiwitan's community in Cigugur, Kuningan faced public resistance on their cemetery construction [11]. Meanwhile, all of our informants actively participated in social activities. They found more acceptance from the public that helped reposition their engagement with the larger community.

\subsection{Women with Disability}

To gather information from women with disabilities, the local researcher interviewed eight women in Yogyakarta from various backgrounds, i.e., lecturers, housewives, domestic workers, social activists and private sector workers. As people with disabilities, they experience greater challenges during the pandemic, besides the stigma that considers them to be disabled people who are unable to carry out certain activities. Nevertheless, they engaged actively in social solidarity, which ensured their acceptance. In general, they are sincere to what has become predestined or "something necessary" as people with different abilities. Their acceptance of their own condition forms a deep and rooted spirituality, which in turn helps them cope with the pandemic.

\section{Discussion}

\subsection{Cohesive Agency and Resilience-Building}

Women at work is a complex phenomenon beyond the traditional feminist vision of liberating women through work, as many of them were not coming from the privileged class, and further complicated with the attachment of women workforce with generally male dominated system [10].

Women's resilience is overwhelming indeed. The COVID-19 pandemic transformed social lives in a radical way, including women's condition. Our research revealed important changes such as women workers turned household cooks, nutritionists, food security maintainers, home teachers, husband psychological counselors, and others, those might be an unpretentious disappearing the split between domestic and public space assignment. Multiple roles carried by many household women during the pandemic suffered their private lives, such as the 
disappearance of me-time, which carried with it the roller-coaster emotional posture, in particular to those with limited domestic space.

Rather than being a traditional site of concession and negotiation between members of the family, between male and female subjects, such as husband and wife in regards of social role, the nuclear family in pandemic tended to intensify the burden to the wife's shoulders, which forced the women to rearrange a new concession space as a compensation, for instance to their husband's loss of the permanent jobs. The situation is different among the family that husband and wife survived their existing jobs and are no more burdened with minors and underage children.

On the other hand, mastery with gadgets for general communication has also expanded as many women transformed themselves into new digital entrepreneurship. We testified the emergence of online entrepreneurship as well not only conducted by the veteran, but by household wives. For many households this online activity, oftentimes the outcome of mutual cooperation and networking with other woman producers, became a new social space for them to support their family. Those who already active in pre-pandemic social initiatives smoothly expanded it during the pandemic. A university girl who also an Instagram endorser extended her social sensitivity by donating $50 \%$ or more of her revenue to social causes, a sensitivity she already set before the pandemic through different activities she was involved with.

At the same time, the creativity of religious women, recognized earlier by some other observations [e.g. 7], to elevate themselves in a religious landscape continuously performed regardless cautious and in constant negotiation. Minor examples of that among the Muslims, notably Muhammadiyah's family during the earlier phase of pandemic many of them were not only taking the lead in maintaining domestic and community resilience, but also endorse their own religious authority in domestic space, as most of religious activities go home. Muslims and Christians passing two important religious holidays, Ramadhan month and Eid al-Fitr (Idul Fitri), and Easter with each reflective spiritual period allowed many religious families maintaining stronger relationships among the family members.

Along with other societal elements, women are actively involved in social solidarity, and the creation of supporting groups. Praise goes to the numerous women's initiatives in the household level, such as collective production of personal protective equipment (PPE) and maskers, and others. Women active in creating new social space, such as women teachers establishing "homeschooling," i.e., creating "schools" at their homes as many students could not afford long-distance learning, or school from home $(\mathrm{SfH})$, which implied the internet connection and gadget possessions. This indeed a negotiation against the government directive that limited the possibility of offline learning in schools, and at the same time a reshape of urban living as they became the agency to disperse learning centers into houses.

Among religious minority groups in our research, Ahmadi's and Sunda Wiwitan's women pandemic enhanced their social space as they involved in solidarity activities which helped them to escape from discriminative eyes. Furthermore, for the Sunda Wiwitan community, the endorsed social and physical distancing simply confirmed their age-old religious practice of measuring the gap between subjects during their worship session.

Hakka's women in Banda Aceh embossed further the women's resilience and highlighted how pandemic allowed for repositioning women in minority groups. Hakka is a microminority among Indonesian Chinese community, which is mainly dominated by Hokkienese. Through their activities within the umbrella of Yayasan Hakka Aceh (Aceh Hakka Foundation, Ya Chin Kechia Ci Chin Huei), they became the field organizers to social activities such as providing cheap street foods, via Warung Murah Fakir Miskin (Inexpensive Food Stall for the Poors) initiative. This interfaith interaction - as they are Christians and 
Buddhists - further strengthened when collaborating with local Acehnese Muslim communities.

\subsection{Inter-spatial Performance}

Some observations indicate that in general Indonesian women "emancipation" still within the curfew of gender ideologies that "place women in the home, as carers of husbands and children," while working women enjoyed only limited autonomy regardless more exposure in the public space [8]. Such conditions in large part are still prominent in the present pandemic.

After six months of pandemic many issues are settled down and some of earlier ordeals, such as the debate, polemic on conducting offline and online worship dissipated. Nonetheless, some are persistent. Household economy remained vulnerable which in many cases forced women to rearrange their domestic and external affairs. Pandemic forced many, including women to redefine the meaning of house and home, family and household -- which in Indonesian those terms appeared more subtle, rumah and rumah tangga.

Inter-spatial performance embraces different modes of presence in space and virtual space. Those spaces became a continuum. It seemed in the first months of pandemic male masculinity was in crisis. Many of the main victims of the infection were males and in the social landscape, those who suffered layoffs found themselves in difficult positions as they lost control of their lives in public while awkward in domestic space. This condition pregnant with potential domestic discord and uneasiness that in many cases a fertile soil for domestic violence. Those who survived came out with stronger husband-wife relationships and rebalancing household roles. Many cases demonstrated the women's mobility to sell products and services, while the domestic handled by the husbands.

As the above indicated that in order to survive, low-income households compelled some women to appear in the virtual world, a fortnight transformation to digital women entrepreneurs. Others inhabit the inter-spatial voids by becoming street vendors, sembako middlewomen, and online sellers for basic foods. Our informant in the Districts of Greater Manggarai (West Manggarai, Manggarai and East Manggarai) initiated Ute Dite (lit. Our Vegetables), a social media-based service for selling farmer's vegetables.

This includes the long-distance household arrangements, popularly known as LDR (longdistance relationship) in which the husbands - mostly the husbands - have to live in distant working places far from the family. While communication technology could cope with the challenge of distance, distantiation is a real problem for the wives who handled the daily routine.

Women in social activism, in particular among the religious-based communities, in this case Catholic nuns in the Regencies of Manggarai and West Manggarai, demonstrated resilience in the pandemic. Their burden increased and they encountered many difficulties, but they also found spiritual empowerment. Since earlier periods of new spiritual women's spaces in medieval Europe, spirituality was a space for self-actualization, notably in convents. Convents were not only a religious institution with specific social function, but it also a spiritual space to claim the sacred feminine. Similar feelings shared by health workers when they found more spiritual empowerment and meaningful life once they aligned their job with religious values.

One of the informers, who organizes a shelter house for the victims of domestic violence, demonstrated the enhanced spatiality and initiatives such as creating the network of social solidarity, providing social spaces for the victims, and furthermore, creating mixed onlineoffline entrepreneurship to support the members of the community. 
Despite the raising awareness and inclusivity, urban, public, interspatial, and domestic space, pre- and during the pandemic remained the same: generally unfriendly to the diffables and people with disabilities [e.g. 13, 1, 15]. This condition gives more gravity for women with disabilities during the pandemic. In terms of social space, many of them need personal assistance for mobility and other necessities, which in turn physical distancing is difficult to implement. The ordeal faced by mainstream religious institutions manifested in the debate of physical or online worship is beyond the problem encountered by our disabled informants. For the accessibility to the house of worship is not yet settled for them. Most of them remained at the peripheral of the sacred spaces.

\subsection{Between Commonality and Incommensurability: Women with Disabilities}

The contrast between commonality and incommensurability of women, in large part is dealing with limited attention of religious authority in meaning making of women's role and performance in the context of pandemic. Many women's actions are considered ordinary and routine, hence slipped from specific theological addressing from religious authorities. This is even more problematic for the diffables and women with disabilities. In general, religious institutions do not provide discourse infrastructure to address the incommensurability.

The social and religious hesitance to deal with the diffables and individuals with disabilities is prevalent. Disability was often connected with both the discourse of purity and pollution, even with morality and sin, which as social scapegoat violence toward them was part of divine sanction and the process of social reintegration [9].

Except some positive cultural imagination, e.g. people with disabilities holding esoteric power [20], modern discourse mainly informed by medical perception and the ideology of developmentalism [6, 12, 15]. Diffability and disabilities are religious and social construction on the ideal of humanity and normalcy. In the social landscape such construction manifested in the debate upon the terminology and the evolution of the term [20, 22, 25]. Such a framework that preserved the marginality condition of the diffables and people with disabilities. Recently, however there were growing religious literatures that are more transformative and sensitive to their experiences [e.g. 5, 12, 20], nevertheless there is still much to work with, in particular in dealing with special cases such as women with disabilities in pandemic context.

Interviewing our informants, i.e., women with visual impairments, hearing and physically disabled, revealed the power of self-religio/spiritual mobilization. Most of them construct their spirituality within the social solidarity intensified during the pandemic. Interestingly further that our informants constructed their own spirituality through redefine the meaning of hikmah (wisdom) and tawakkal (trust), introduced by both Muslim and Christian informants. That pandemic is not seen as a negative force, God's punishment, but as medical reality in which part of God's purposive plan. Others elucidated further by emphasizing the dimension of "blessing in disguise" as they have opportunities to (re-)manage their lives: making stronger social connections, creating a more hygienic environment, and forced to be more creative to survive the daily challenges. Nevertheless, those spiritualities are hardly an instant product of religious spontaneity. Their marginal situation in the pre-pandemic provided a stronger base for the present resilience and endurance.

\section{Conclusion}


The three aforementioned highlights on cohesive agency and resilience-builder, women's interspatial performance, and the challenge of commonality and incommensurability, might easily fall into the glorification of women and its roles during the pandemic. Pandemic shifts in a painful way the interpersonal relationship between male and female, the meaning of household, and social arrangement at large. The scope of challenges resisted the exclusive claim of a single agency that both suffered and transformed. Everybody is in pain. Furthermore, we attested the tandem of male-female partnership in dealing with difficult situations, and larger social solidarity created by all walks of life, including cross-confessional and interfaith initiatives.

Nevertheless, the pandemic affected us differently. Women are more vulnerable in different levels, while the social transformation made by women indeed prominent, a major building block in maintaining social cohesion and resilience, in community and domestic level, regardless less recognized and maneuvering within the persistent gender ideology. Besides, limited religious meaning making for the appropriation of women's role and performance is rather frustrating, in particular for women with disabilities.

Our research suggests for greater appreciation of women's contribution, including religious recognition of their important role in shaping domestic religiosity, and for strategic actors for community endurance.

\section{Acknowledgements}

The present paper is the outcome of a cluster of research projects entitled "Reshaping New Urban Living: Indonesian Women and Coronavirus," under the umbrella project of Religion and COVID-19, organized by the Indonesian Consortium for Religious Studies (ICRS) and the Center for Religious and Cross-cultural Studies (CRCS), coordinated by Zainal Abidin Bagir, funded by Ford Foundation and Hibah Riset Dikti. It could not have been possible without the support of our local researchers. We are grateful to Denni Pinontoan, Jessy Ismoyo, Lintang Citra Maharani, Maurisa Zinira, Max Regus, Siti Aliyuna Pratisti, Subandri Simbolon, Teuku Muhammad Jafar, and Virdei Eresto, for their services.

\section{References}

[1] Aisyah, L. \& Maftuhin, A. 2019. Kontribusi UIN Sunan Kalijaga Yogyakarta dalam Studi Disabilitas di Indonesia. Panangkaran: Jurnal Penelitian Agama dan Masyarakat. 3 (2), 71. DOI:https://doi.org/10.14421/panangkaran.2019.0301-05.

[2] Alon, T.M., Doepke, M. Olmstead-Rumsey, J., \& Terlit, M. 2020. The Impact of COVID-19 on Gender Equality. National Bureau of Economic Research.

[3] Badan Pusat Statistik 2020. Statistik Indonesia 2020 (Statistical Yearbook of Indonesia). Badan Pusat Statistik.

[4] Chairani, I. 2020. Dampak Pandemi COVID-19 dalam Perspektif Gender di Indonesia. Jurnal Kependudukan Indonesia. Edisi Khusus Demografi dan COVID-19, (Jul. 2020), 39-42.

[5] Christiani, T.K. 2016. Pendidikan Kristiani dan Disabilitas. Keberpihakan dan Kepedulian Lintas Iman untuk Difabel. Interfidei. 37-52.

[6] Coleridge, P. 1993. Disability, Liberation, and Development. Oxfam.

[7] Doorn-Harder, P. van 2006. Women shaping Islam: Indonesian women reading the Qur'an. University of Illinois Press. 
[8] Ford, M. \& Parker, L. eds. 2008. Women and work in Indonesia. Routledge.

[9] Girard, R. 1977. Violence and the sacred. Johns Hopkins University Press.

[10] hooks, bell. 2000. Feminist Theory. From Margin to Center. South End Press.

[11] Indrawardana, I. 2020. Menhir Yang Ternistakan. Suara Muda News.

[12] Maftuhin, A. 2020. Islam dan Disabilitas: Dari Teks ke Konteks. Gading Publishing.

[13] Maftuhin, A. 2017. Mendefinisikan Kota Inklusif: Asal-usul, Teori dan Indikator. Tataloka. 19 (2), 93.

[14] Menengok Peran Perempuan dalam Pandemi Covid-19: 2020. https://www.cnnindonesia.com/gayahidup/20200421143955-284-495691/menengok-peran-perempuan-dalam-pandemi-covid-19. Accessed: 2020-09-03.

[15] Nugroho, S. \& Utami, R. 2004. Meretas siklus kecacatan: realitas yang terabaikan. Yayasan Talenta \& The Ford Foundation.

[16] Postill, J. \& Epafras, L.C. 2018. Indonesian Religion as a Hybrid Media Space: Social Dramas in a Contested Realm. Asiascape: Digital Asia. 5 (1), 100-123.

[17] Sex, gender and COVID-19: disaggregated data and health disparities: 2020. https://blogs.bmj.com/bmjgh/2020/03/24/sex-gender-and-covid-19-disaggregated-data-and-healthdisparities/. Accessed: 2020-09-20.

[18] Soseco, T. 2020. Lessons from COVID-19: Small and Financially Strong Family. Jurnal Kependudukan Indonesia. Edisi Khusus Demografi dan COVID-19, (Jul. 2020), 49-52.

[19] TEMPO Editor 2020. Editorial: Urgensi Undang-Undang Anti-Kekerasan Seksual. TEMPO.

[20] Thohari, S. 2012. Habis Sakti, Terbitlah Sakit: Berbagai Macam Konsepsi Difabel di Jawa. Diskusi Salihara, 1-16.

[21] UN Women 2020. Action Brief: Women, Peace, Security and COVID-19 in Asia and the Pacific. UN Women Regional Office for Asia and the Pacific.

[22] UU No. 8/2016 2016. UU No. 8/2016 tentang Penyandang Disabilitas.

[23] Wenham, C., Smith, J., \& Morgan, R. 2020. COVID-19: the gendered impacts of the outbreak. The Lancet. 395, 10227, 846-848.

[24] Why Covid-19 is different for men and women: 2020. https://www.bbc.com/future/article/20200409-why-covid-19-is-different-for-men-and-women . Accessed: 2020-09-20.

[25] Widinarsih, D. 2019. Perkembangan Istilah Disabilitas di Indonesia. Jurnal Ilmu Kesejahteraan Sosial. 20 (2), 127-142. 